\title{
Tax Administration, Tax Incentive and SMEs' Growth: The Moderating Effect of Firms Size
}

\author{
Isaac Kwadwo Anim ${ }^{1}$; Emelia Awotwe²; Kwamena Minta Nyarku³ ${ }^{3}$ Lawrence Yaw Kusi ${ }^{4}$ \\ ${ }^{1,3,4}$ School of Business, University of Cape Coast, Ghana \\ E-mail:ianim@ucc.edu.gh ${ }^{1}$; knyarku@ucc.edu.gh ${ }^{3}$; lawrence.kusi@ucc.edu.gh ${ }^{4}$ \\ ${ }^{2}$ Nursing And Midwifery Training College, P.O. Box TP 59, Twifo-Praso, Ghana \\ E-mail: emelia_awotwe@yahoo.com \\ https://doi.org/10.47963/jobed.2020.06
}

\begin{abstract}
The study examined the effect of tax administration and tax incentives on the growth of small and medium enterprises in the Kumasi Metropolis of Ghana. Explanatory research design supported by the quantitative research approach was employed. Structured questionnaires were administered for the collection of the primary data from 115 SMEs operating in the metropolis. The multiple regression results revealed that tax administration accounts for a statistically significant positive weak variance in SMEs' growth, whilst tax incentives account for a statistically significant positive moderate variance in SMEs' growth. Firm size moderates the predictive relationship between tax administration and SMEs' growth. Medium enterprises have higher propensity in terms of tax compliance compared to small enterprises. Medium enterprises also have higher growth potential than small enterprises. Ghana Revenue Authority should implement preferential tax policies that support SMEs growth in Ghana with much emphasis on tax incentive packages to small enterprises.
\end{abstract}

Keywords: Tax administration, tax incentives, compliance, business growth, firm size, small and medium enterprise 


\section{Introduction}

Most businesses in African, to which Ghana is part, are by size, small and medium-size enterprises (SMEs). These SMEs cover a spectrum of economic sectors and are found in both developed and developing countries (Olawale \& Garwe, 2010; Peci, et a., 2012). Globally, SMEs produce around 70\% of jobs and account for 35\% of GDP in developing countries, while 55\% of GDP in developed countries (Xu, Li, Liang \& Rahman, 2019). The growth of SMEs has attracted attention from both researchers and governments in developing countries, because of SMEs' potential to address unemployment, stimulate innovation and contribute to local development to promote economic growth (Musamali \& Tarus, 2013; Xu et al., 2019). SMEs account for $92 \%$ of businesses in Ghana and absorb $60 \%$ of Ghana's labour force and contribute 22\% to GDP of Ghana (Koranteng, Osei-Bonsu, Ameyaw, Ameyaw, Agyemang \& Dankwa, 2017). More so, SMEs provide inputs to large-sized enterprises (Cant \& Wiid, 2016) and contribute to governments' revenue through taxation (Amoako, 2013; Swistak, 2016).

The era of progressive taxation is ending globally, morphing towards revenue-neutral taxation and oriented towards internalizing externalities (Kiser \& Karceski, 2017). A good tax regime for small firms is a key policy tool to pave their way out of the "informality trap" of low growth, limited access to markets, and exclusion from formal financial services (Masanja, 2019; Kenyon, Thomas \& Kapaz, 2005; Akelentera, 2011). Taxation refers to any compulsory transfer of money from citizens of a country to the government as a source of revenue (Ameyaw, Korang, Twum \& Asante, 2016; Akolgo, 2012). Taxation is the process whereby a state or government exacts contributions from its citizens or from the residents of its territory for the maintenance of the state machinery (Plehn, 1924; AliNakyea, 2008). However, to effectively and efficiently mobilise as much revenue as desired depends on the level of compliance of the taxpayers to pay tax. Tax compliance refers to taxpayers' willingness to pay their taxes (Kirchler, 2007). It deals with the ability and willingness of taxpayers to comply with tax laws, declare the correct income in each year and pay the right amount of taxes on time (Internal Revenue Service Act, 2000 Act 592; Income Tax Act, 2015 Act 896).

SMEs often face unhealthy competition from, large foreign multinational companies hence threatening their growth and survival of these SMEs (Atawodi \& Ojeka, 2012). The use of growth as a measure of firm performance is generally based on the belief that growth is a precursor to the attainment of sustainable competitive advantages and profitability (Markman \& Gartner, 2002). Growth is a multi-dimensional measure of performance in that different measures are used for it in different contexts (Fitzsimmons, Steffens \& Douglas, 2005). In situations where a country's tax structure is not effectively designed in line with the conditions prevailing in particular environment and economy in which the SMEs operate, it may produce a significant tax burden on the tax paying enterprises and, consequently, its incidence impacting end users, due to changing ability of taxes (Xu, Li, Liang \& Rahman, 2019).

Tax is a necessary evil. Unfavourable taxes end up increasing cost of running businesses, slows their growth and increases the cost of production (Xu et al., 2019). Some countries have tax systems that are structured purely towards revenue generation (Kinyua, 2013). Such is the perception of SMEs in Ghana (Ameyaw, Korang \& Twum, 2016). Tax policies in developing countries discriminate against SMEs, but rather support larger firms that have higher tax revenue payback returns than SMEs with lower tax revenue payback returns (Bird \& Wallace, 2003). Businesses, indeed, complain of paying double taxes along the value chain (Ali-Nakyea, 2008), hence the significant negative inverse relationship between taxes and business survival and sustainability (Atawodi \& Ojeka, 2012). In Nigeria, 80\% of SMEs wind up before their $5^{\text {th }}$ anniversary because of unfavorable tax system (Atawodi and Ojeke, 2012).

An overly complex regulatory system and tax regime, or one opaque in its administration and enforcement, makes tax compliance unduly burdensome, with frequent distortionary effect on the development of SMEs as they are tempted to transform into forms that offer a lower tax burden or no tax burden at all (Masato, 2009). Tax compliance among SMEs is generally low (Mukhlis \& Simanjuntak, 2016; Engelshalk, 2004). A study by Adebisi and Ghegi, (2013) on SMEs in developing countries has revealed the ignorance of research into how taxation affect development, survival and growth of SMEs. Huge taxes imposed on companies affect their profitability ratio, dividend policies, growth and survival (Gravelle, 2012; Huston, 2016). SMEs perceive negative impact of tax policies on their growth in Accra (Tee, Boadi \& Opoku, 2016), their tax evasive behaviour (Kraus, 2002), such as passing all profits and losses onto their shareholders (Brealey \& Myers, 2000). Moreover, SMEs are known to face the problems of high tax rates, multiple taxation, lack of proper information and complex regulatory policies (Xu, et al., 2019).

Tax incentives in the developing countries are rather limited (Zee \& Stotsky, 2002), thereby failing to attract investment in SMEs (James \& Van Parys, 2010; Abbas, Klemm, Park \& Bedi, 2012). Besides, lack of or minimal tax exemptions to SMEs in Ghana hinder the SMEs' expansion drive and growth potential compared with those in the advanced economies (Ameyaw, Korang \& Twum, (2016). Some countries experiencing bad administration, in general, have resorted to partially privatizing their tax administration (Kiser \& Karceski, 2017).

Evidence on the association between firm size and firm growth proves to be contradictory (Bigsten \& Gebreeyesus, 2007). Some studies have produced negative results (Mead \& Liedholm, 1998; Gunning \& Mengistae, 2001; Sleuwaegen \& Goedhuys, 2002), although other similar studies revealed higher growth potential for medium enterprises (Stella, Aggrey \& Eseza, 2014) and large enterprises (Van Biesebroeck 2005), but no relationship was 
found in other studies, such as that of Harding, So"derbom and Teal (2004). Firm growth is a complex issue as metrics for assessing growth are inherently crucial and there is empirical evidence of slow growth among businesses (Goswami, 2019). Besides, high growth may not imply high productivity (Goswami, 2019). Growth is difficult to achieve and even more difficult to sustain (Lim, Morse \& Yu, 2020). Firm size is a significant determinant of tax compliance (Yusof, Ling \& Wah, 2014). Medium enterprises pay taxes than small enterprises (Okpeyo, Musah \& Gakpetor, 2019). Medium enterprises paid higher taxes compared to small enterprises (Hendricks, Amit \& Whistler, 1997). Others also believe small firms bear higher tax compliance costs than larger companies (Lokhande, 2020), hence having higher default risk of non-payment. These findings are contradictory and need further investigation.

In this study, the researchers comprehensively examine how tax system measured by tax administration and tax incentives in Ghana affect growth of SMEs, given the interacting effect of firm size. The study is inherently linked with SDG 8, which seeks to promote decent work and economic growth of all nations by 2030, as championed by the United Nations Agenda. The study believes favourable tax system could foster SMEs' growth and decent work, which would eventually translate into economic growth of Ghana. Tax authorities and agencies could rely on the findings of this study to develop business-friendly tax policies to promote the survival and growth of SMEs whilst amassing revenue to support Ghana's developmental agenda. The remaining sections provide information in respect of literature, research methods, results, discussion, conclusion, implications, limitation and suggestion for further studies.

\section{Literature Review}

Tax administration and SMEs' growth

According to Pfister (2009), African governments are challenged as to how to find optimal balance between tax regime that is business and investment friendly and leverage enough revenue for public service delivery. Taxation is the process whereby a state or government exacts contributions from its citizens or from the residents of its territory for the maintenance of the state machinery (Akolgo, 2011). Taxes are also imposed on corporate entities (Plehn, 1924). Tax is any compulsory transfer of money from citizens of a country to the government as a source of revenue (Ameyaw, Korang, Twum \& Asante, 2016). Multiple taxes that come in different forms are imposed on businesses in Ghana (PwC Ghana, 2014). Most of these taxes are charged on supply of goods and services that is a taxable supply and is made by a taxable person in the course of its taxable activity. A taxable activity means an activity, whether or not for a pecuniary profit, carried on by a person in Ghana or partly in Ghana that involves the supply of goods or services to another person for consideration (PwC Ghana, Ghana Tax Facts and Figures Report, 2019). Ghana's tax system is characteristically discriminatory and multi-tax system (Ameyaw, Korang \& Twum, 2016).

Tax reforms in Ghana seek to create friendly business environment for investors and entrepreneurs (Armah-Attoh $\&$ Awal, 2013). Such reforms are intended towards revenue sufficiency, equity simplicity and economic efficiency (Bekoe, Danquah \& Senahey, 2016). Recent stride in tax reforms in Ghana is the integration of all the three major tax revenue institutions - Internal Revenue Service (IRS), the VAT Service and the Customs, Excise and Preventive Service (CEPS) - into a single agency, The Ghana Revenue Authority (GRA), to enhance effective tax administration system in Ghana. How well a tax administration works depends, to a considerable extent, on the environment within which it works (Bird \& de Jantscher, 1992). The nature of tax structure and the underlying legal system is one factor as is the extent to which taxation is used to achieve objectives other than simply collecting revenue. Good tax system focuses on the collection of information to as to promote transparency, certainty and assurance. Tax administration, therefore, provides means to shaping economic development in an effective manner (Bird \& de Jantscher, 1992).

Growth may be volatile and episodic (Grover Goswami, Medvedev \& Olafsen, 2019). Firm growth is conceptualized as the expansion of dynamic resource system (Lim, Morse \& Yu, 2020). According to Gibrat's law, growth is independent of firm size because each firm is believed to have optimal size given market conditions, management capability and transaction cost (Goswami, Medvedev \& Olafsen, 2019). However, from the perspective of the evolutionary competition, insufficient incumbents (firms) are forced out of market and their resources are absorbed by more efficient firms. Firm growth propels firms to create job, generate output of high quality and transforms economic lives of business and economies (Goswami, Medvedev \& Olafsen, 2019). Businesses with growth potential generate larger market share, distribute returns to investors, achieve high productivity, generate revenue and withstand fierce competition (Ayyagari, et a., 2018).

From the perspective of the necessity theory, government is the necessity of the state and revenue is the necessity of the government, hence the imposition of tax on the necessity to generate revenue (Stuebs \& Whiteaker-Poe, 2018). Supported by the subject and the object theory, governments have jurisdiction control of all its subjects and, therefore, use their power to make subjects the object of taxation based on their sovereign authority (Stuebs \& Whiteaker-Poe, 2018). The essence the exercise of the state power is to create a welfare state in which everyone benefits from the exercise of the authority of the state. Therefore, agents responsible for tax administration are to run an efficient tax system. Good tax administration system for SMEs is characteristically simplistic, proportionate, certain, neutral, fair 
and trade-offs (Jousten, 2007). It is envisaged that a good tax administration produces better conditions that positively influence the business climate which, in turn, creates the necessary conditions of businesses to flourish. This situation would translate into improved business growth.

For instance, (Adefeso, 2018) discovered that a good corporate tax policy improves firm performance. Tax education induces voluntary tax compliance for SMEs that are educated by tax officials in Ghana, especially on VAT returns than those SMEs that are not educated (Adom, Amakye, Doh \& Anku, 2013). Dabla-Norris, et al., (2017) opined strong tax administration exerts significant positive impact on small and young businesses. Tee, Boadi and Opoku (2016) found that tax policies in Ghana have adverse impact on SMEs' growth. This position was also fueled by Nyarku and Oduro (2017) in their empirical study that found that trade regulations, tight monetary and credit policies, corruption, and excessive tax regime negatively hamper SMEs' growth in Ghana. Inferring from these, one can deduce that favorable tax administration contributes favourably to business growth, hence we hypothesise that:

H1 Tax administration significantly predicts positive change in SMEs' growth.

Tax incentives and SMEs' Growth

State agents manage tax systems by exercising authorities conferred on them by the state to collect tax and remit returns and reliefs (Kiser \& Karceski, 2017). A decrease in the rate of corporate tax increases the incentives for incorporation (Agbenyo, 2016) and thereby increases after-tax earnings. Tax incentives refers to an exemption or relief granted to an individual or a firm to reduce the effect of taxation and thus encourage savings and investment (Chukwumerije \& Akinyomi, 2011). Numerous incentives have been incorporated into the Ghanaian tax system over the years. Notable among such incentives, as claimed by tax authorities, include, but not limited to, tax rebates, reduced tax rates, tax holidays, incomes exempted, capital allowances, fresh graduate incentives, free-zone incentives, double tax treaties, capital gains exempted, import duty exemptions and exempted export duties (PwC Ghana, Ghana Tax Facts and Figures Report, 2019; Ugwu, 2018; Bekoe, Danquah \& Senahey, 2016). The creation of some special incentives is based on industry type, number of years of operating, nature of transactions, business size and origin of businesses and so forth (PwC Ghana, Ghana Tax Facts and Figures Report, 2019). Market failures negatively affect SMEs due to their sizes and ages in the business life cycle. Again, tax system disproportionally goes against SMEs. These hard-hit conditions inform collectively call for SME support in terms of preferential treatments (Bozdoğanoğlu, 2016).

Tax incentives are underlined by the benefit theory of tax that advances taxes that agents pay should reflect the benefit that they receive from the mix of good and services they enjoy from the state (Neill, 2000). The benefits theory of tax sets the standard lens through which local taxation is based (Scherf \& Weinzierl, 2020). It, therefore, posits taxes should be zero or low for entities and individuals who receive no benefits from the state and high for those entities and individuals that derive the most benefits. Infrastructural developments that are initiated by the government provides the greatest benefits to firms (Stewart, 2015). The agency theory of tax incentive posits that tax incentives compensate for other government-created obstacles in the business environment, thus using tax to respond to fiscal failure as much as market failure (Twesige \& Gasheja, 2019). Therefore, granting incentive packages in the tax system is to propel the growth of businesses in the country so as to support government's agenda of economic growth, national development, job creation and improved general welfare of the citizenry.

Some empirical studies support this position. Megersa (2019) found that tax incentives in China contribute to predicting GDP growth, has positive effect on research and development expenditure in Taiwan, and causes sizeable increase in employment, output, fixed capital and number of firms in India. Again, Siyanbola, Adedeji, Adegbie and Rahman (2017) also discovered that tax incentives are significant strategic drive for business and industrial growth in Sub-Saharan States including Ghana. Besides, the more governments make revenue, the more they are better positioned to provide incentives to tax payers (Siyanbola, et al., 2017). Empirically, it is found that tax exemptions decrease tax burden of SMEs more than that of tax rates (Liakhoyets, 2014), which positions them to reinvest their capital for their efficient functioning. Government's support such as tax reduction and simplification of tax system also stimulate SMEs' growth (Louis \& Macamo, 2011). Tax reduction, lower tax amount payable and tax exemption could support the growth SMEs (Bozdoğanoğlu, 2016). In a given empirical comparative study in Uganda, it was discovered that firms with incentives performed better than firms without incentives in terms of gross sales and value added (Mayende, 2013). Better still, streamlining tax incentives was a strong stimulus to improving firm performance (Mayende, 2013). Particularly, Twesige and Gasheja (2019), in their recent study, found that tax incentives are predictors of sustainable SME growth in Rwanda. Hence, it is hypothesised that:

H2 Tax incentives significantly predict positive variance in SMEs' growth.

H3 Tax incentives significantly mediate the predictive relationship between tax administration and SME growth. 
Firm size as a moderator

There is lack of definite understanding of SMEs (Gibson \& Van Der Vaart, 2008). However, there are various definitions of SMEs, but there exists no universally acceptable or consistent definition for the term SMEs (Beger \& Udell, 2002). Irrespective of the variance in such definition, certain variables, such as value of fix assets, number of permanent employees and turnover, are common (Mbizi et al., 2013). The European Union (EU) defines SME as an enterprise with employee capacity of 10 and 250 and a turnover of $€ 50$ million (EC, 2009). The World Bank (2013) defines SMEs as enterprises with a maximum of 300 employees, $\$ 15$ million in annual revenue and $\$ 15$ million in assets. Kuug (2016) defines SMEs as companies with not more than 500 employees. In lieu of the different definitions proposed by different authors and institutions, this research adopted the definition by the National Board for Small Scale Industries (2015). Small enterprises are operationalized as businesses employing between 6 and 29 and medium enterprises with between 30 and 99 workforce or have fixed assets not exceeding 100,000 USD. Small enterprises are not financially positioned compared to larger firms, especially in the era of global competition in domestic markets (Gamage, et al., 2020).

The ability to pay theory posits that tax burden should differ between taxpayers in proportionate manner such that heavier burden falls on those who are better able to bear it. The ability pay theory further proposes that those who have more should rather pay more, thereby justifying progressive tax system (Kendrick, 1939). From this standpoint, it is expected that medium enterprises are to have higher tax compliance capacity compared to small enterprises, since medium enterprises are better positioned financially in terms of their level of profitability compared to small enterprises. Besides, compliance is justified by the ability to pay, hence firms with more resources are better positioned to pay their taxes on time than those with limited resources. The operational definition of SMEs by the European Commission, the World Bank and the National Board for Small Scale Industries signals the financial strength of medium enterprises over small enterprises.

Stella, Aggrey and Eseza (2014) found that firm size significantly relates with firm growth in Uganda. Medium enterprises grew faster than small enterprises (Stella, et a., 2014). Others found an inverse relationship between firm growth and firm size (Hart \& Oulton, 1999; Mata Portugal, 2004). Keating (1974) also discovered that larger firms grow faster than small ones. Singh and Whittington (1975) also found that large firms grow faster. Contrary to these claims, Dunne and Hughes (1994) found that small grow faster than large firms. However, Okpeyo et al. (2019) found that medium enterprises pay taxes more than small enterprises. Hendricks, Amit and Whistler (1997) further disclosed that medium enterprises pay higher taxes compared to small firms. XX Contrary to the above positions, Dabla-Norris, Mish, Cleary and Khawaja (2017) found that tax compliance costs disproportionately higher for small and young businesses compared to large and old firms. Firm size is treated as a moderator in numbers studies, including business strategy and firm performance (Kannadhasan, 2009), functional integration and firm performance (Ali, Mukulu, Kihoro \& Nzulwa, 2016), sustainable supply chain management and sustainable performance (Wang, Zhang \& Goh, 2018), innovation and firm performance (Kijkasiwat \& Phuensane, 2020). These empirical studies and the theoretical positions espoused show that firm size has the capacity to influence the relationship between tax administration and business growth. Thus, firm size is a key determining factor of firm growth in the face of tax administration, hence we hypothesise that:

H4: $\quad$ Firm size significantly moderates positively the effect of tax administration on SME growth

Tax compliance differences for small-sized enterprises and medium-sized enterprises

It is not an easy task to persuade taxpayers to comply with tax requirements, since tax represents unaccounted cost (James \& Alley, 2005). Tax evasion is persistent in developing countries (Atawodi \& Ojeka, 2012). Tax compliance refers to taxpayers' willingness to pay their taxes (Kirchler, 2007). Contextually, tax compliance captures the ability and willingness of taxpayers to comply with tax laws, declare the correct income in each year and pay the right amount of taxes on time (Internal Revenue Service Act, 2000 Act 592). Tax compliance covers the reporting of all incomes and payment of all taxes by fulfilling the provisions of laws, regulations and court judgments (Alm, 1991; Jackson \& Milliron, 1986). Singh (2003) extended this and opines tax compliance is a person's act of filing their tax returns, declaring all taxable income accurately, and disbursing all payable taxes within the stipulated period without having to wait for follow-up actions from the authority. Tax compliance is operationalized as the willingness of taxable entities to act in accordance with the spirit and the letter of tax law and administration without the application of enforcement. Tax non-compliance is taxpayer's failure to remit a proper amount of tax, perhaps on account of the complexity or even contradictions in the tax legislation or tax administration procedure (Kesselman, 1994).

To tackle the issue of non-compliance, most tax regimes integrate punitive measures, such as fines, closure or even jail term, to enforce compliance (Swistak, 2016). Compliance cost, poor internal controls, tax rates (Mwangi, 2014), auditing of account/tax assessment, referral group and tax knowledge (Inasius, 2015), fairness, prompt enforcement (Swistak, 2015), attitude (Nkwe, 2013), high tax rates and complex filing procedure determine SMEs' tax compliance behaviour. Ameyaw et al. (2016) claim that taxes cannot be avoided without attracting punishment. Differences in tax compliance behaviour between small and medium enterprises may again be attributed to the 
position of the ability to pay tax theory espoused earlier (Kendrick, 1939). Empirically, in Tanzania, Masanja (2019) found that issues, such as high taxes, multiple taxes unreasonable taxes, unfriendly attitude of tax administrators, difficulty in paying taxes, bureaucracy in paying taxes and changes in taxes, affect tax compliance behaviour for SMEs. Firm size positively related significantly with ability to pay tax (Ocheni \& Gemade, 2015). For instance, Mukhlis and Simanjuntak (2016) found low tax compliance behaviour among SMEs. Elsewhere in Greater Accra, Okpeyo, Musah and Gakpetor (2019) found that tax compliance is higher among medium enterprises than small firms. Others also believe small firms bear higher tax compliance costs than larger companies hence having higher default risk of non-payment (Atawodi \& Ojeka, 2012; Lokhande, 2020). We, therefore, hypothesise that:

H5: $\quad$ There is a statistically significant difference in likelihood of tax payment for SEs and MEs.

Growth differences for small-sized enterprises and medium-sized enterprises

Gartner (1990) opines that business growth is a major theme of entrepreneurship. Growth is characterized with mixed results in literature (Fitzsimmons, Steffens \& Douglas, 2005) partly because different measures are used for its measurement (Delmer, Davidsson \& Gartner, 2003). The use of growth as a measure of firm performance is generally based on the belief that growth is a precursor to the attainment of sustainable competitive advantage and profitability (Markman \& Gartner, 2002). Growth epitomizes the process of in-depth development and positive improvement that is generally measured through quality, and/or profit improvements (Diabate, Sibiri, Wang \& Yu, 2019). Finance, number of workers, quality of labour skills, business expansion/branches, product lines, business innovation, search for improvement, market development, sales revenue, productivity, integration of IT in business processes are key measures of SMEs' growth (Xu et al., 2019). Business growth also connotes some element of sustainability (Fitzsimmons, Steffens \& Douglas, 2005), although not static (Delmer, et al., 2003). Firm size matters in several instances when it comes to determining firm growth and development (Nguyen \& Ramachandran, 2006).

The transaction cost theory provides a basis for the utilization of non-market modes of organisation. The theory posits that firms reduce transaction costs based on their impact on incentives, monitoring and structure of production (Williamson, 1998). Co-ordination cost incurred on all information processing necessary to co-ordinate the work of tax authorities and that of SMEs are more likely to favour medium size enterprises than small enterprises. Inferring from this analogy, it is envisaged that small businesses that are financially weak comparatively may as well be unwilling to grow as much as medium enterprises, because taxes paid by such firms possibly weaken their production capability, thereby affecting their growth potential negatively (Dagdeviren \& Robertson, 2016).

Medium enterprises possess economies of scale; therefore, their production costs are likely to be lower compared to small enterprises, which equally put small enterprises in unfavorable financial position, thereby limiting their growth capacity. Gibrat's Law predicts that all firms have the same likelihood of growth rate. However, Edmiston (2007) found that large firms are more innovative than small enterprises, which eventually positions larger firms to grow faster than small firms. McKenzie and Sakho (2010), in their empirical study, concluded that tax registration appears to improve profitability of mid-sized firms significantly compared to smaller firms, which positions midsized firms to grow better than smaller firms. Whittington (1975) found that firm growth is highly dependent of firm size. Similar view was expressed by Stella, Aggrey and Eseza (2014), that medium enterprises grew faster than small enterprises. Based on these assertions, we hypothesise that:

H6: $\quad$ There is a statistically significant difference in SME growth for SES and MEs.

Based on the overall logic overriding the interrelationship among the constructs, which originated from ideas generated through theoretical review, empirical findings and research interest of the researchers, the conceptual framework is presented (see Figure 1). 


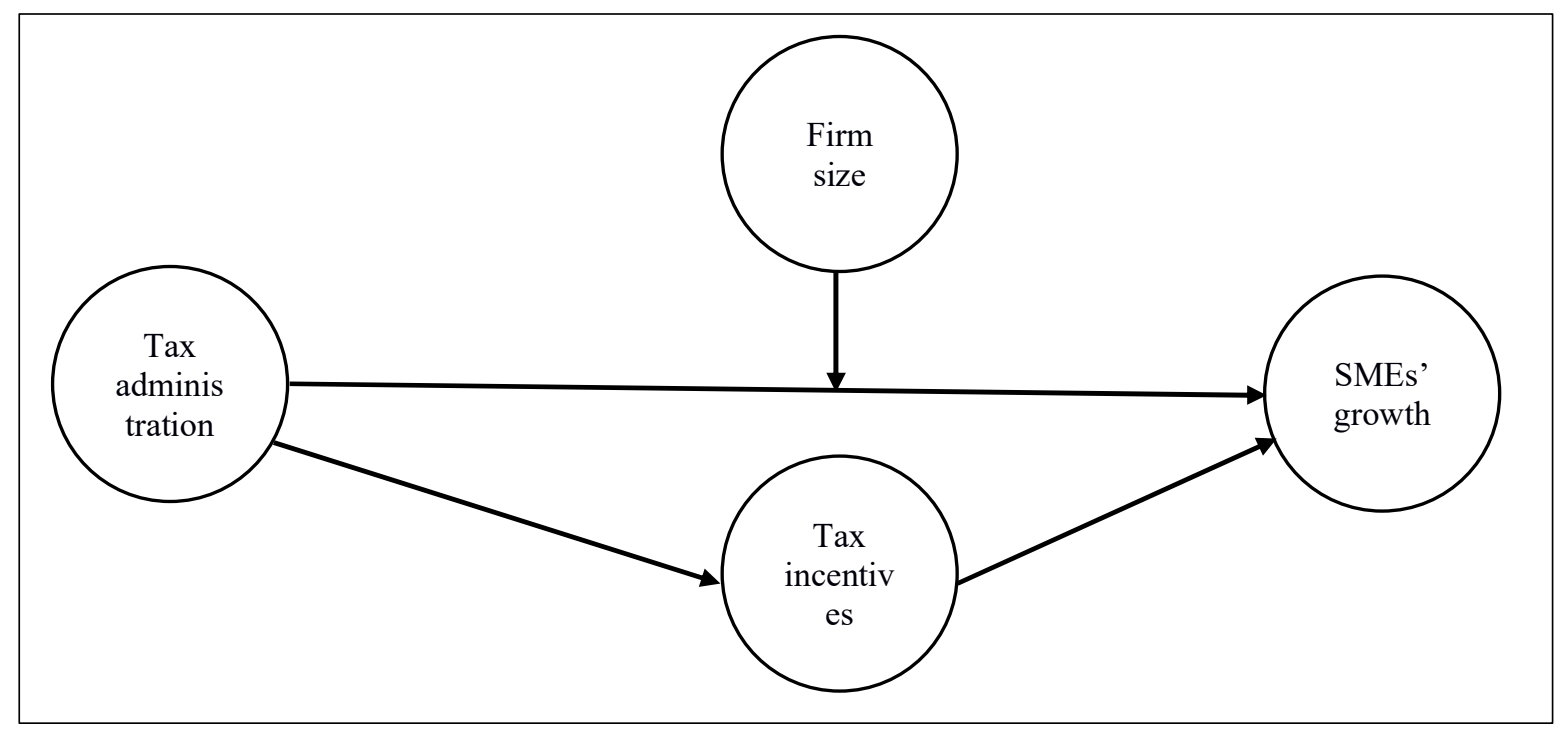

Figure 1: Conceptual Framework

\section{Methodology}

The study employed the explanatory research design and quantitatively approached the measurement and analysis of the primary data. The study targeted 153 registered SMEs operating in Kumasi Metropolis. Since the unit of analysis was at the firm level, owners and/or managers of SMEs across many different industries were surveyed through structured questionnaire administration. Kumasi Metropolis is one of the thirty (30) districts in the Ashanti Region. It is located between Latitude $6.35 \mathrm{oN}$ and $6.40 \mathrm{oS}$ and Longitude $1.30 \mathrm{oW}$ and $1.35 \mathrm{oE}$ and elevated 250 to 300 meters above sea level. The economic activities sustaining the livelihood of the residents in the Metropolis are categorised into service, industry and agriculture (Kumasi Metropolitan Assembly Composite Budget Report, 2014). Most of these businesses are SMEs (Kumasi Business Advisory Center-Kumasi Metropolitan Assembly, 2017).

The sample size (115) was determined based on a sample size formula propounded by Slovin, (1973). The participants were selected through systematic sampling technique. The registered SMEs were given unique identification number and after the first sample had been selected randomly, the remaining participants were selected next after each one (1) count until all the 115-sample size was obtained. For SMEs' growth, respondents were asked to indicate how their businesses have grown given the current tax administration and incentives on a 5-point Likert scale rated from 1-No improvement-5-Very great improvement (12 items). The items were obtained from empirically validated sources (Nastasiea \& Mironeasa, 2019; Wiklund, Patzelt \& Shepherd, 2009; Dobbs \& Hamilton, 2007; Diabate, Sibiri, Wang \& Yu, 2019; Dalrymple, 2004). On measuring tax administration, the respondents were asked to indicate their level of satisfaction with the tax administration items (8 items) on a 5-point Likert scale rated as follows: $1=$ Not at all satisfied to 5-Extremely satisfied. Tax incentive ( 7 items) was also measured a 5-point Likert scale. The respondents were asked to which they agree that the tax incentive variables promote the growth of their businesses on a 5 -point Likert scale rated $1=$ Not at all in agreement- $5=$ To a very great extent. The indicators of tax administration and tax incentives were also obtained through extant literature review (Masanja, 2019; PwC Ghana, Ghana Tax Facts and Figures Report, 2019; Ugwu, 2018; Bekoe, Danquah \& Senahey, 2016; Osei \& Quartey, 2005).

Structured questionnaires were administered for the gathering of the primary data. Participants were formed about the purpose of the study. Consents from all participants were formally sought. Ethically, no participant was forced to participate in the study. Confidentiality, anonymity and privacy of the participants were strongly assured throughout the entire research period. No data manipulation was carried out. Primary data collection took 3 months (December, 2017-Febrauary, 2018). Drop-and-pick self-administration of the questionnaires was carried out. A 100\% response rate was obtained. The data was cleansed, and imputed into the SPSS version 25.0 (configured with SPSS process Macro version 3.4) for data processing and analysis. Data transformations were carried out in respect of constructs after those constructs' validity and reliability had been checked and approved under the lens of statistical techniques so as to support holistic data analysis in the SPSS process macro (Domfeh, Kusi, Nyarku \& Hunsaker, 2018; Nyarku et al., 2018). Standard multiple regression (For H1; H2), mediation analysis with process macro (H3), moderation analysis with process macro (For $\mathrm{H4}$ ), and independent sample t-test (For H5; H6) were employed for the analysis primary data in respect of the formulated hypotheses. These approaches to testing the hypotheses are validated in some previous empirical studies (Domfeh, Kusi, Nyarku \& Ofori, 2018). 
Common method bias, which represents the amount of spurious correlation among the variables, may be generated by utilising the same method, such as survey, so as to measure each variable, was measured with the Harman's single factor method. Some procedural mechanisms, such as negating some items (reserved coded), using different rating scales for different construct, counter-balancing the order of measurement of the dependent and independent variables, careful construction of the scale items, protecting the anonymity of the participants, separating the measurement of the scales, obtaining the measures of the dependent and independent variables from different validated sources, were followed, as prescribed by Tehseen, Ramayah and Sajilan, (2017). Statistically, Harman's single factor method was employed to detect the presence of common method bias after these procedural techniques were employed to avoid the occurrence this problem. Internal consistency was measured with the Cronbach's Alpha $(\mathrm{CA}>0.07)$. The findings are presented in Table 1.

Table 1: Reliability Results

\begin{tabular}{lcc}
\hline Construct & Cronbach's Alpha & Number of Item \\
\hline SME growth & 0.8954 & 12 \\
Tax administration & 0.828 & 8 \\
Tax incentive & 0.744 & 7 \\
\hline
\end{tabular}

The subscales were also reliable given the primary data collected, because internal consistency measured by the Cronbach's Alpha was above the minimum thresholds of 0.70 (Kusi, Domfeh \& Kim, 2018; Bujang, Omar \& Baharum, 2018). Content validity of the scale was ensured since the inclusion of items was subjected to rigorous scrutiny in the light of previous empirical studies. Confirmatory factor analysis was conducted through principal component factor analysis to examine the validity of the subscales considered in this study.

Table 2: MO and Bartlett's Test

\begin{tabular}{lcccc}
\hline & & & \\
& & & \\
& & & \\
Kaiser-Meyer-Olkin Measure of Sampling Adequacy. & 0.675 & SMEs' growth & Tax administration \\
Bartlett's Test of Sphericity & Approx. Chi-Square & 308.239 & 0.887 & 0.686 \\
& Df & 55 & 4500.842 & 439.001 \\
& Sig. & 0.000 & 0.000 & 28 \\
& & & 0.000 \\
\hline
\end{tabular}

The KMO measure of sample adequacy and Bartlett's test of sphericity shows tax incentives (KMO=mediocre), SMEs' growth (KMO=Meritorious) and tax administration $(\mathrm{KMO}=$ Mediocre $)$ the sample size for the factor analysis adequate and spherical (see Table 2).

Validity: Tax Incentives

The component rotated matrix shows that the items measuring tax incentives are valid, because factor scores of more than 0.3 were obtained for all the indicators (see Table 3 ).

Table 3: Component Matrix ${ }^{\mathrm{a}}$

\begin{tabular}{lc} 
& Component \\
\hline Tax rebates & 1 \\
Tax holidays & .569 \\
Reduced tax rates & .421 \\
Incomes exempted & .484 \\
Capital allowances & .581 \\
Fresh graduate incentives & .356 \\
Free-zone incentives & .531 \\
Double tax treaties & .628 \\
Capital gains exempted & .520 \\
Import duty exemptions & .673 \\
Exempted export duties & .477 \\
\hline
\end{tabular}

Extraction Method: Principal Component Analysis.

a. 1 components extracted. 
Validity: SMEs' growth

The component rotated matrix shows the items measuring SMEs' growth are valid because factor scores of more than 0.3 were obtained for all the indicators (see Table 4 ).

Table 4: Component Matrix ${ }^{\mathrm{a}}$

\begin{tabular}{lc}
\hline & Component \\
\hline Increased asset acquisiton & 1 \\
Increased number of employees & .803 \\
Improved retention of profit & .815 \\
Improved profitability & .847 \\
Better pricing & .869 \\
Increased number of branches & .690 \\
Improved investment funds & .793 \\
Business innovation & .839 \\
Access to loan & .796 \\
Improvement in asset & .840 \\
\hline
\end{tabular}

Extraction Method: Principal Component Analysis.

a. 1 components extracted.

Validity: Tax administration

The component rotated matrix shows the items measuring tax administration are valid because factor scores of more than 0.3 were obtained for all the indicators (see Table 5).

Table 5: Component Matrix ${ }^{\mathrm{a}}$

Modes of tax payment

Component

1

Timing of corporate tax payment

.686

.655

Corporate tax rates

.808

Corporate tax amounts

.807

Tax administration system efficiency

.792

Corporate tax incentives

.643

Perceived certainty in corporate tax

.592

Tax education by GRA

.422

Extraction Method: Principal Component Analysis.

a. 1 components extracted.

Common Method Bias

Harman's single factor method was employed to measure common method bias (Tehseen, Ramayah \& Sajilan, 2017). The results proved that there was no threat of common method bias for tax incentives and tax administration because they recorded a $\%$ of variance far less than $50 \%$ (see Table 6). This was, however, not the case of SMEs' growth.

Table 6: Total Variance Explained

\begin{tabular}{|c|c|c|c|c|c|c|}
\hline \multirow[b]{2}{*}{ Component } & \multicolumn{3}{|c|}{ Initial Eigenvalues } & \multicolumn{3}{|c|}{ Extraction Sums of Squared Loadings } \\
\hline & Total & $\begin{array}{c}\% \text { of } \\
\text { Variance }\end{array}$ & Cumulative \% & Total & $\%$ of Varianc & Cumulative $\%$ \\
\hline 1 (Tax incentives) & 3.150 & 28.634 & 28.634 & 3.150 & 28.634 & 28.634 \\
\hline 1 (SMEs' growth) & 6.654 & 66.539 & 66.539 & 6.654 & 66.539 & 66.539 \\
\hline 1 (Tax administration) & 3.772 & 47.155 & 47.155 & 3.772 & 47.155 & 47.155 \\
\hline
\end{tabular}

Test of normality (SMEs’ growth) 
The Z-scores (Statistics/Std. Error) for the positively skewed SMEs' growth (Z-score for skewness=1.8319) and negatively kurtotic SMEs' growth (Z-score for Kurtosis=-1.8658) falls within the range of -1.96 and 1.96 (see Table 7), hence the conclusion that the data in respect of SMEs is approximately normally distributed (Pallant, 2005).

Table 7: Descriptives

\begin{tabular}{llcc}
\hline & & Statistic & Std. Error \\
\hline SME growth & Mean & 25.8609 & 1.00159 \\
& $95 \%$ Confidence Interval for Mean & Lower Bound & 23.8767 \\
& Upper Bound & 27.8450 \\
& & 25.3865 \\
& & 24.0000 \\
Median & 115.366 \\
Variance & 10.74088 \\
Std. Deviation & 12.00 \\
Minimum & 52.00 \\
Maximum & 40.00 \\
Range & 20.00 \\
Interquartile Range & .414 \\
Skewness & -.834 \\
\hline
\end{tabular}

\section{Results}

The study surveyed $87(75.7 \%)$ male and 28 (24.3\%) female managers/owners of registered SMEs in the Kumasi Metropolis. 69.6\% (80) were managers whilst 30.4\% (35) were CEOs of the SMEs. 91 (79.1\%) were small enterprises whilst 24 (20.9\%) were medium enterprises. Most of these SMEs were in the service sector $57(49.6 \%)$, which seemingly confirms the growth of the service sector in Ghana, $35(30.4 \%)$ in manufacturing, $13(11.3 \%)$ in agriculture whilst the remaining $10(8.7 \%)$ in commerce. Most of the SMEs relied on self-financing (49/42.6\%), combination of self-financing and debt (loan) financing (46/40.0\%), debt financing $(13 / 11.3 \%)$ and combination of debt (loans), self-financing and leasing (7/6.1\%). Most of the SMEs (105/91.3\%) were registered tax payers at the Ghana Revenue Authority. 10/8.7\% of the SMEs were not registered taxpayers. Most of the SMEs had been in business between $6-10$ years $(37 / 32.2 \%)$ followed by those between $1-5$ years $(35 / 30.4 \%)$. The remaining $26(22.6 \%)$ and $17(14.8 \%)$ had had business experience between $11-15$ years and 16 years and above, respectively. $72(62.6 \%)$ were sole proprietorship, $36(31.3 \%)$ were private companies whilst the remaining $7(6.1 \%)$ were into partnership. At least, all respondents have secondary educational background. Majority had First Degree Certifictes (54/47\%) and then followed by those with HND/Equivalent Certificates (37/32.2\%). 13 (11.3\%) and 11 (9.6\%) of the participants had Masters' Degree and SHS/equivalent certificates respectively.

Test of Hypotheses: $H_{1}$

The tested hypotheses results show there is a strong positive significant joint correlation between measures of tax administration and SME growth $(\mathrm{R}=0.613 ; \mathrm{p}=0.000$ : $\mathrm{p}<0.05)$ (see Table 8$)$. Tax administration accounts for $37.6 \%$ positive significant variance in SMEs' growth. This variance in SMEs' growth as accounted for by changes in tax administration is significantly moderate $\left(\mathrm{R}^{2}>0.33 ; \mathrm{p}=0.000: \mathrm{p}<0.05\right)$. Other factors that have the potential to improve SMEs' growth apart from tax administration but are not captured in the model could account for the remaining $62.4 \%$ variance in SMEs' growth. $\boldsymbol{H}_{\boldsymbol{1}}$ is thus supported in this study.

Table 8: Model Summary ${ }^{\mathrm{b}}$

\begin{tabular}{lccccc}
\hline & & & & Std. Error of the & Sig \\
Model & $\mathrm{R}$ & R Square & Adjusted R Square & Estimate & \\
\hline 1 & $.613^{\mathrm{a}}$ & .376 & .328 & 8.80190 & 0.000 \\
\hline
\end{tabular}

Table 9: Coefficient

\begin{tabular}{|c|c|c|c|c|}
\hline \multirow[b]{2}{*}{ Model } & \multicolumn{4}{|c|}{ Unstandardized Coefficients } \\
\hline & $\mathrm{B}$ & Std. Error & $\mathrm{T}$ & Sig. \\
\hline (Constant) & 13.611 & 4.380 & 3.107 & .002 \\
\hline
\end{tabular}




\begin{tabular}{lcccc} 
Mode of corporate tax payment & .953 & 1.435 & .664 & .508 \\
Timing for tax payment & -2.113 & 1.361 & -1.553 & .123 \\
Tax rates & -3.459 & 1.658 & -2.086 & .039 \\
Tax amounts & 2.236 & 1.627 & 1.374 & .172 \\
Perceived certainty in corporate tax & 3.093 & 1.233 & 2.509 & .014 \\
Tax incentives & 2.530 & 1.081 & 2.340 & .021 \\
Tax administration efficiency & -.296 & .938 & -.315 & .753 \\
Tax education by GRA & 2.312 & .917 & 2.523 & .013 \\
\hline
\end{tabular}

Observation of the beta coefficient (Unstandardized Coefficients) shows that only four measures of tax administration make a statistically significant positive contribution to the positive change in SME growth (see Table 9). This claim is substantiated by the $p$ values. These indicators include corporate tax rate $(\mathrm{Beta}=-3.459 ; \mathrm{p}=0.039)$, perceived certainty in corporate tax $(3.093 ; \mathrm{p}=0.014)$, corporate tax incentives $($ Beta $=2.530 ; \mathrm{p}=0.021)$ and tax education by GRA (2.312; $<<0.013)$. A regression function is therefore deduced as follows:

$S M E$ growth $=13.611-3.459$ (Corporate tax rate) +3.093 (Perceived tax certainty) +2.530 (Tax incentives) +2.312 (Tax education by GRA)

Test of Hypotheses: $\mathrm{H}_{2}$

Table 10: Model Summary

\begin{tabular}{lccccc}
\hline Model & R & R Square & Adjusted R Square & $\begin{array}{c}\text { Std. Error of the } \\
\text { Estimate }\end{array}$ & Sig \\
\hline 1 & $0.658^{\mathrm{a}}$ & 0.434 & 0.373 & 8.50423 & 0.000 \\
\hline
\end{tabular}

The joint correlation between tax incentives and SMEs' growth is strong positive moderate and significant $(\mathrm{R}=0.658$; $\mathrm{p}=0.000: \mathrm{p}<0.05$ ) (see Table 10). Tax incentives account for a statistically significant positive variance in SMEs' growth $\left(\mathrm{R}^{2}=0.434 ; \mathrm{p}=0.000: \mathrm{p}<0.05\right)$. This variance in SMEs' growth as accounted for by changes in tax incentives is significantly moderate $\left(\mathrm{R}^{2}>0.33 ; \mathrm{p}=0.000\right.$ : $\left.\mathrm{p}<0.05\right)$. Other factors that have the potential to improve SMEs' growth apart from tax incentives but are not captured in the model could account for the remaining 56.6\% variance in SMEs' growth. Therefore, $\boldsymbol{H}_{2}$ is supported.

Table 11: Coefficient

\begin{tabular}{llcccc}
\hline \multicolumn{1}{c}{ Model } & & Unstandardized Coefficients & & \\
& & $\mathrm{B}$ & Std. Error & $\mathrm{T}$ & Sig. \\
\hline 1 & (Constant) & 11.678 & 4.094 & 2.853 & .005 \\
& Tax rebates & 3.425 & .844 & 4.058 & .000 \\
& Tax holidays & 2.799 & .861 & 3.252 & .002 \\
& Free zones incentives & .402 & .994 & .405 & .687 \\
& Incomes exempted & -.377 & .776 & -.486 & .628 \\
& Capital allowances & -.410 & .935 & -.439 & .662 \\
& Fresh graduate incentives & -.268 & .880 & -.304 & .762 \\
& Reduced tax rates & 3.365 & .969 & 3.472 & .001 \\
& Double tax treaties & -.811 & 1.119 & -.725 & .470 \\
& Capital gains exempted & -.728 & 1.095 & -.664 & .508 \\
& Import duty exemptions & .744 & .994 & .749 & .456 \\
Exempted export duties & -1.779 & .866 & -2.053 & .043 \\
\hline
\end{tabular}

On the individual contributions of the predictive variables to the $43.4 \%$ positive variance in SME growth, the study shows tax rebates $($ Beta $=3.425 ; p=0.000)$, tax holidays (beta $=2.799 ; p=0.002)$, reduced tax rates $(B e t a=3.365$; $\mathrm{p}=0.001)$ and exempted export duties $($ Beta $=-1.779 ; \mathrm{p}=0.043)$ are significant positive predictors of SMEs' growth (see Table 11). A regression function is therefore deduced as follows:

$S M E$ growth $=11.678+3.425$ (Tax rebates) +2.799 (Tax holidays) +3.365 (Reduced tax rates) $-1.779($ Exempted export duties) 
Test of Hypotheses: $\mathrm{H}_{3}$

Table 12: Normal theory tests for indirect effect

\begin{tabular}{rccc}
\hline Effect & se & $\mathrm{Z}$ & $\mathrm{p}$ \\
\hline .2150 & .1113 & 1.9316 & .0534 \\
\hline
\end{tabular}

A Sobel test was conducted and found full mediation in the model $(\mathrm{z}=0.1113, \mathrm{p}=0.0534)$. The indirect contribution of tax incentive in the model was statistically significant (effect $=0.2150 ; p<0.05$ ) (see Table 12). It is, therefore, concluded that tax incentive fully significantly mediates the impact of tax administration on SME growth in the Kumasi Metropolis. Again, to reinforce this mediation claim, a quick observation in changes in the $\mathrm{R}^{2}$ values for the model that included both predictors (tax administration and tax incentive) and the model that had only tax administration shows a difference of $0.0293\left(\mathrm{R}^{2}: 0.2034-\mathrm{R}^{2}: 0.1741\right) . \boldsymbol{H}_{3}$ is, therefore, supported.

Test of Hypotheses: $\mathrm{H}_{4}$

Table 13: R-square increase due to interaction(s):

\begin{tabular}{cccccc}
\hline & R2-chng & $\mathrm{F}$ & $\mathrm{df1}$ & $\mathrm{df2}$ & $\mathrm{p}$ \\
\hline int_1 & .0273 & 4.6817 & 1.0000 & 111.0000 & .0326 \\
\hline
\end{tabular}

A close observation of impact of the interaction effect in the model shows $0.0273(2.73 \%)$ change in SMEs growth is attributed to the interaction between business size and tax administration significantly $(p=0.032: p<0.05)(s e e$ Table 13). Therefore, $\boldsymbol{H}_{4}$ is supported.

Test of Hypotheses: $\mathrm{H}_{5}$

$\underline{\text { Table 14: Independent Sample T-Test }}$

\begin{tabular}{|c|c|c|c|c|c|}
\hline \multicolumn{2}{|c|}{$\begin{array}{c}\text { Levene's Test for } \\
\text { Equality of } \\
\text { Variances }\end{array}$} & \multirow[b]{2}{*}{$\mathrm{T}$} & \multirow[b]{2}{*}{ Df } & \multirow[b]{2}{*}{ Sig. (2 tailed) } & \multirow[b]{2}{*}{$\begin{array}{c}\text { Mean } \\
\text { Difference }\end{array}$} \\
\hline $\mathrm{F}$ & Sig. & & & & \\
\hline .124 & .725 & -2.672 & 113 & .009 & -.84890 \\
\hline
\end{tabular}

The firm-size difference on tax compliance shows medium enterprises $(\mathrm{M}=2.7500 ; \mathrm{SD}=1.45213 ; \mathrm{N}=24)$ have greater tendency to comply with payment of taxes than small size enterprises $(\mathrm{M}=1.9011 ; \mathrm{SD}=1.36671 ; \mathrm{N}=91)$. This difference is statistically significant $\mathrm{t}([113]=-2.672 ; \mathrm{p}=0.009$ : $\mathrm{p}<0.05)$ with very small effect size (eta squared $=0.0594$ ) (see Table 14). This finding shows $5.94 \%$ variance in tax compliance is explained by firm size. Therefore, $\boldsymbol{H}_{5}$ is supported.

Test of Hypotheses: $\mathrm{H}_{6}$

Table 15: Independent Sample

\begin{tabular}{|c|c|c|c|c|c|}
\hline \multicolumn{2}{|c|}{$\begin{array}{c}\text { Levene's Test for } \\
\text { Equality of } \\
\text { Variances } \\
\end{array}$} & \multirow[b]{2}{*}{$\mathrm{T}$} & \multirow[b]{2}{*}{ Df } & \multirow[b]{2}{*}{$\begin{array}{l}\text { Sig. (2 } \\
\text { tailed) }\end{array}$} & \multirow[b]{2}{*}{$\begin{array}{c}\text { Mean } \\
\text { Difference }\end{array}$} \\
\hline $\mathrm{F}$ & Sig. & & & & \\
\hline .363 & .548 & -3.158 & 113 & .002 & -7.49496 \\
\hline
\end{tabular}

Medium enterprises $(M=31.7917 ; \mathrm{SD}=9.37610 ; \mathrm{N}=24)$ have greater tendency to grow than small size enterprises $(\mathrm{M}=10.57407 ; \mathrm{SD}=10.57407 ; \mathrm{N}=91)$ (see Table 15). Difference in SMEs' growth is statistically significant $\mathrm{t}([113]$ $=-3.158 ; \mathrm{p}=0.002: \mathrm{p}<0.05$ ) with moderate effect size (eta squared $=0.0811$ ). Therefore, $8.11 \%$ variance in $\mathrm{SME}$ growth is explained by business size. It is conclusive that $\boldsymbol{H}_{\boldsymbol{6}}$ is supported. 


\section{Discussion}

Holistically, the first model shows that tax administration causes a statistically significant positive moderate variance in SME growth. This finding supports $\mathrm{H}_{1}$. This finding justifies the position of the benefit theory of tax that advances the argument that taxes that agents pay should reflect the benefit that they receive from the mix of good and services they enjoy from the state (Neill, 2000), thereby setting the standard lens through which local taxation is based (Scherf \& Weinzierl, 2020). The finding is explained by the logic that since government creates the environment and climate for business growth, SMEs, in turn, comply with the directives regarding tax administration, and this eventually leads to improved business growth among the SMEs. It is important to acknowledge that key aspects of tax administration that strongly and positively predict improvement in SMEs' growth include corporate tax rates, corporate tax incentives and tax education by GRA. The mode of tax payment, tax amount and efficiency of tax administration as measures of tax administration do not have a significant bearing on the growth of SMEs in the Kumasi Metropolis. The joint significant positive correlation between tax administration and SME growth contradicts the position of Atawodi and Ojeka (2012), that there is a negative relation between taxes and business growth. The positive significant impact of tax administration on SMEs' growth in this research contradicts some empirical claims (Ojeka, 2011; Mungaya, et al., 2012; Ameyaw, et al., 2016; Koranteng et al., 2017), which collectively found a negative impact of tax on SMEs' growth, but supports the position of other empirical studies (Adefeso, 2018; Tee, Boadi \& Opoku, 2016).

Tax incentives are recognized as a significant positive predictor of SMEs' growth in the Kumasi Metropolis, in particular, and Ghana, as a whole. This impact is justified by the position of the agency theory of tax incentive that indicates that tax incentives compensate for other government-created obstacles in the business environment. Thus, using tax to respond to fiscal failure as much as market failure (Twesige \& Gasheja, 2019). Therefore, granting incentive packages in the tax system propels the growth of businesses in the country so as to support government's agenda of economic growth, national development, job creation and improved general welfare of the citizenry. The position of the benefit theory of tax that indicates that tax agents are willing to pay taxes that reflect the benefits they receive from the mix of goods and services they enjoy from the state (Neill, 2000) is also justified, as the study reveals that SMEs in Ghana receive some benefits from the tax system in the country through tax incentive packages. These incentive packages, thus, provide good grounds for SMEs to function effectively. Incentives, thus, support SMEs by lifting their tax burden, encourage savings and boost investment drive (Dai, Verreynne, Wang \& He, 2020; Chukwumerije \& Akinyomi, 2011; Zee, Zee, Stotsky \& Ley, 2002).

The finding echoes the claim collectively held by some previous empirical studies, that tax incentives significantly improve SMEs' growth (Megersa, 2019; Siyanbola et al., 2017; Liakhovets, 2014; Siyanbola, 2017; Adefeso, 2018; Megersa, 2019). Tax incentive packages, having significant influence on SMEs' growth, include tax rebates, reduced tax rates, tax holidays, and exempted tax duties. Free zone incentives, incomes exempted, capital allowances, fresh graduate incentives, double tax treaties, capital gain tax are insignificant predictors of SMEs' growth in the Kumasi Metropolis. Although tax administration contributes to growth of SMEs, this growth is, however, enhanced if SMEs are given business-friendly tax incentives by the tax authorities in Ghana (Liakhovets, 2014; Siyanbola, 2017; Adefeso, 2018; Megersa, 2019). Supporting the ideals of the benefits theory of taxation, it is deduced that SMEs benefit from the government of Ghana through the tax incentive packages that are offered to them. This situation ends up creating the supportive environment for tax administration to better improve the state of growth of SMEs in the Kumasi, in particularly, and Ghana, at large.

Firm size is a significant factor that influences the effect of tax administration's influence on SMEs' growth in Ghana. This supports the position held by a recent empirical study by (Okpeyo, Musah and Gakpetor (2019). Given the significant interactive effect of firm size, the study further proves that medium enterprises have higher likelihood to pay taxes, compared to small-sized enterprises in Ghana. It, therefore, signifies that small enterprises have greater default risk compared to medium enterprises. The magnitude of the difference is very small. This finding justifies the position of the transaction cost theory that firms reduce transaction cost based on its impact on incentives, monitoring and structure of production (Williamson, 1998). Therefore, co-ordination cost incurred on all information processing necessary to co-ordinate the work of tax authorities and that of SMEs are more likely to favour mediumsized enterprises than small enterprises. This position is also championed by some empirical studies (e.g., Okpeyo, Musah \& Gakpetor, 2019; Ocheni \& Gemade, 2015; Stella, et al., 2014). Comparatively, medium enterprises have greater growth potential within the current tax system operating in Ghana, compared to small enterprises, although the magnitude of the difference is moderate. This position is supported by some previous empirical studies (e.g., Stella, Aggrey \& Eseza, 2014; Bourlakis, Maglaras, Aktas, Gallear \& Fotopoulos, 2014).

\section{Conclusion}

The tax system in Ghana is favourable for SMEs' growth, given the significant positive contributions of tax administration and tax incentives to predicting SMEs' growth. Tax incentives enhance the effect of tax administration on SMEs' performance significantly. Firm size is a significant factor that influences tax compliance and growth of 
SMEs in Ghana. Medium enterprises have high growth potential and tax compliance behaviour, compared to small enterprises.

For theoretical purposes, it is believed that the findings of the study support the principles inherent in the benefit theory. The participants disclosed that they pay taxes to the government of Ghana because they receive some benefits from the state and also expect the state to spend the revenue collected by way of taxes to boost the economic outlook and general business environment in Ghana. The agency theory of tax incentive is equally supported as the study unravels the rationale behind tax administration and SMEs' growth, given the intervening effect of tax incentives. Also, the study established some empirical relationships among the constructs considered in the models of the study, especially on how favourable tax administration system and tax incentives positively impact on the growth of SMEs. Firm size seems to be a significant factor that influences how tax system affects SMEs' growth in Ghana.

For practical purposes, Ghana Revenue Authority (GRA) and its allies are encouraged to put in place systems that make tax administration efficient, convenient and business-friendly, so as to promote compliance behaviour among SMEs in the Kumasi Metropolis and Ghana, at large. To fully enhance the effect of tax administration on growth of SMEs in a significant manner, GRA must charge attractive corporate tax rates, ensure SMEs are certain as to the type, amount and time of payment of taxes, provide general tax incentives and also conduct full scale consistent tax education for SMEs.

The study shows tax incentives improve SMEs' growth significantly and on a moderate scale, hence special focus on providing tax incentives to SMEs in Ghana should be the strategic drive of GRA, if the authority is to stimulate SMEs' growth through tax incentives in Ghana. Tax rebates, tax holidays, reduction in tax rates and tax exemption duties are prime drivers of SMEs' growth in the context of the study, hence the government's fiscal policy must focus on these incentive packages for SMEs, to promote their growth. At the moment, tax incentives, such as free zone incentives, income tax exemption, double tax treaties, capital gains exemption and import duties, do not support the growth of SMEs. Hence, there is the need for tax authorities to repackage these elements in order to improve their effect significantly on SMEs' growth in the Kumasi Metropolis. Small enterprises need to be given preferential treatment through the government of Ghana's fiscal policies through incentive packages. This is because the small enterprises need more push financially in order to stimulate their growth and tax compliance behaviour as compared to the medium enterprises. This initiative could assist small enterprises to migrate to medium enterprises in the long run, given their growth potential. The government of Ghana can institute fiscal and monetary policies that support the growth of SMEs and refocus high growth SMEs operating in the Kumasi Metropolis.

The moderation and the mediation analyses were done with the composite variables and this made it impossible to observe the contributions of the individual indicators of the constructs used for such analysis. Again, the findings of this study cannot be generalised to cover all sizes of businesses, because it did not target micro enterprises and large enterprises operating in the Kumasi Metropolis. Further studies should be conducted to assess the influence of taxation on growth of micro enterprises and large enterprises in Ghana. 


\section{References}

Abbas, S. M., Klemm, A., Park, J., \& Bedi, S. (2012). Quantifying structural subsidy values for systemically important financial institutions.

Abe, M. (2009). SMEs in Asia and the Pacific. Studies in Trade and Investment, 65, 1-31.

Adebisi, J. F., \& Gbegi, D. O. (2013). Effect of multiple taxation on the performance of small and medium scale business enterprises: A study of West African Ceremics Ajeokuta, Kogi State. Mediterranean Journal of Social Sciences, 4(6), 323.

Adefeso, H. A. (2018). Government tax policy and performance of listed manufacturing firms in Nigeria: Evidence from dynamic panel data model. Zagreb International Review of Economics and Business, 21(1), 1-16.

Adom, P. K., Amakye, K., Doh, E., \& Anku, R. (2013). SMEs record keeping in Ghana: Has VAT made it better? International Journal of Economics and Financial Issues, 4(1), 152-169.

Agbenyo, D. (2016). Challenges facing small and medium scale enterprises (SMEs) in accessing credit: A Case Study of Kumasi Metropolis. (Unpublished doctoral thesis), Kwame Nkrumah University of Science and Technology, Kumasi, Ghana.

Ahrholdt, D., Gudergan, S. \& Ringle, C. (2019). Enhancing loyalty: When improving consumer satisfaction and delight matters. Journal of Business Research. 94, 18-27.

Akolgo, P. A. (2011). Encouraging growth and formalization of small businesses through tax reforms: A study of the Tamale Metropolis in the Northern Region. Unpublished doctoral thesis.

Alegana, H. M. (2014). The effect of tax incentives on economic growth in Kenya. (Unpublished MBA dissertation), University of Nairobi, Nairobi, Kenya.

Ali, M. J., Mukulu, E., Kihoro, J. M., \& Nzulwa, J. D. (2016). Moderating Effect of Firm Size on the Relationship between Functional Integration and Firm Performance. International Journal of Academic Research in Business and Social Sciences, 6(9), 38-57.

Ali-Nakyea, A. (2008). Taxation in Ghana: principles, practice and planning. (2 ${ }^{\text {nd }}$ ed.). Accra: Black Mask Ltd.

Alley, C., \& James, S. (2005). The use of financial reporting standards-based accounting for the preparation of tax returns. International Tax Journal, 31, 31.

Allingham, M. G., \& Sandmo, A. (1972). Income tax evasion: A theoretical analysis. Journal of Public Economics, 1, 323-338.

Alm, J. (1991). A perspective on the experimental analysis of taxpayer reporting. The Accounting Review, 66(3), 577-593.

Ameyaw, B., Korang, J., Twum, E., \& Asante, I. (2016). Tax policy, SMES compliance, perception and growth relationship in Ghana: An empirical analysis. British Journal of Economics, Management \& Trade, 11(2), $1-11$.

Amoako, G. K. (2013). Accounting practices of SMEs: A case study of Kumasi Metropolis in Ghana. International Journal of Business and Management, 8(24), 73.

Anane, G. K., Cobbinah, P. B., \& Manu, J. K. (2013). Sustainability of small and medium scale enterprises in rural Ghana: The role of microfinance institutions. Asian Economic and Financial Review, 3(8), 1003.

Armah-Attoh, D., \& Awal, M. (2013). Tax administration in Ghana: Perceived institutional challenges. Afrobarometer, Briefing Paper, 124.

Atawodi, O. W., \& Ojeka, S. A. (2012). Factors that affect tax compliance among small and medium enterprises (SMEs) in North Central Nigeria. International Journal of Business and Management, 7(12), 87.

Ayyagari, M., Demirgüç-Kunt, A., \& Maksimovic, V. (2018). Financing SMEs and economic development. In Handbook of Finance and Development. Edward Elgar Publishing.

Babatunde, O. A., Ibukun, A. O., \& Oyeyemi, O. G. (2017). Taxation revenue and economic growth in Africa. Journal of Accounting and Taxation, 9(2), 11-22.

Bekoe, W., Danquah, M., \& Senahey, S. K. (2016). Tax reforms and revenue mobilization in Ghana. Journal of Economic Studies.

Berger, A. N., \& Udell, G. F. (2002). Small business credit availability and relationship lending: The importance of bank organisational structure. The Economic Journal, 112(477), F32-F53.

Bigsten, A., \& Gebreeyesus, M. (2007). The small, the young, and the productive: Determinants of manufacturing firm growth in Ethiopia. Economic Development and Cultural Change, 55(4), 813-840.

Bird, R. M., \& de Jantscher, M. C. (1992). Improving tax administration in developing countries (Vol. 19). Washington DC: International Monetary Fund.

Bird, R., \& Wallace, S. (2003). Is it really so hard to tax the hard-to-tax? The context and role of presumptive taxes. International Tax Program Papers, (0307).

Biswas, S., Chakraborty, I., \& Hai, R. (2017). Income inequality, tax policy, and economic growth. The Economic Journal, 127(601), 688-727. 
Bourlakis, M., Maglaras, G., Aktas, E., Gallear, D., \& Fotopoulos, C. (2014). Firm size and sustainable performance in food supply chains: Insights from Greek SMEs. International Journal of Production Economics, 152, $112-130$.

Bozdoğanoğlu, B. (2017). Tax issues arise from a new economic model: Sharing economy. International Journal of Business and Social Science, 8.

Brealey, R. A., \& Myers, S. C. (2000). Theory and practice of corporate finance. Prague, Czech Republic: Viktoria Publishing.

Bujang M. A., Omar E.D., \& Baharum N.A. (2018). A review on sample size determination for Cronbach's Alpha test: A simple guide for researchers. Malays J Med Sci. 25(6)85-99.

Cant, M. C., \& Wiid, J. A. (2016). The use of traditional marketing tools by SMEs in an emerging economy: A South African perspective. Problems and Perspective Management, 14(1), 64-70.

Chow, C. Y. (2004). Gearing up for the self-assessment tax regime for individuals. Tax Nasional, 2, 20-23.

Chukwumerije, T., \& Akinyomi, O. (2011). The impact of tax incentives on the performance of small-scale enterprises. Published Thesis, Redeemer's University, Ogun State, Nigeria.

Dabla-Norris, M. E., Misch, F., Cleary, M. D., \& Khwaja, M. (2017). Tax administration and firm performance: new data and evidence for emerging market and developing economies. International Monetary Fund.

Dagdeviren, H., \& Robertson, S. A. (2016). A critical assessment of transaction cost theory and governance of public services with special reference to water and sanitation. Cambridge Journal of Economics, 40(6), 1707-1724.

Dahlby, B., \& Ferede, E. (2012). The effects of tax rate changes on tax bases and the marginal cost of public funds for Canadian provincial governments. International Tax and Public Finance, 19(6), 844-883.

Dai, X., Verreynne, M. L., Wang, J. H., \& He, Y. (2020). The behavioral additionality effects of a tax incentive program on firms' composition of R\&D investment. $R \& D$ Management.

Dalrymple, J. F. (2004). Performance measurement for SME growth: A business profile benchmarking approach. In Second World Conference on POM and 15th Annual POM Conference, Cancun, Mexico, April.

Delmar, F., Davidsson, P., \& Gartner, W. B. (2003). Arriving at the high-growth firm. Journal of Business Venturing, 18(2), 189-216.

Diabate, A., Sibiri, H., Wang, L., \& Yu, L. (2019). Assessing SMEs' sustainable growth through entrepreneurs' ability and entrepreneurial orientation: An insight into SMEs in Côte d'Ivoire. Sustainability, 11(24), 7149.

Dobbs, M., \& Hamilton, R. T. (2007). Small business growth: Recent evidence and new directions. International Journal of Entrepreneurial Behavior \& Research.

Domfeh, H. A., Kusi, L. Y., Nyarku, K. M., \& Ofori, H. (2018). The mediating effect of customer satisfaction in the predictive relation between celebrity advertising and purchase intentions in telecom industry in Ghana: University Students' Perspective. International Journal of Business and Management Invention (IJBMI), 7(3), 40-54.

Dunne, J. \& Hughes, A. (1994). Age, size, growth and survival: UK companies in the 1980s, Journal of Industrial Economics, 42(2), 115-40.

Edmiston, K. D. (2007). The role of small and large businesses in economic development. Available at SSRN 993821.

Engelshalk, M. (2004). Creating a Favorable Tax Environment for small business in: J. Alm, J. Martinez-Vazquez and S. Wallace, eds. Taxing the Hard-to Tax: Lessons from Theory and Practice. Amsterdam: Elsevier.

Egyin, K. B. (2011). Assessing the challenges of tax revenue mobilisation in Ghana: A case of Sunyani municipality. (Unpublished doctoral thesis), Institute of Distance Learning, Kwame Nkrumah University of Science and Technology, Kumasi, Ghana.

Fitzsimmons, J., Steffens, P., \& Douglas, E. (2005). Growth and profitability in small and medium sized Australian firms. Proceedings AGSE Entrepreneurship Exchange, Melbourne.

Gamage, S. K. N., Ekanayake, E. M. S., Abeyrathne, G. A. K. N. J., Prasanna, R. P. I. R., Jayasundara, J. M. S. B., \& Rajapakshe, P. S. K. (2020). A Review of Global Challenges and Survival Strategies of Small and Medium Enterprises (SMEs). Economies, 8(4), 1-24.

Gartner, W. B. (1990). What are we talking about when we talk about entrepreneurship? Journal of Business Venturing, 5(1), 15-28.

Ghana National Board for Small Scale Industries Report, 2015.

Gibson, T., \& Van der Vaart, H. J. (2008). Defining SMEs: A less imperfect way of defining small and medium enterprises in developing countries.

Goedhuys, M., \& Sleuwaegen, L. (2010). High-growth entrepreneurial firms in Africa: A quantile regression approach. Small Business Economics. 34,31-51.

Grover Goswami, A., Medvedev, D., \& Olafsen, E. (2019). High-growth firms: Facts, fiction, and policy options for emerging economies. The World Bank.

Gravelle, J. (2012). Moving to a territorial income tax: Options and challenges. Congressional Research Service, Library of Congress. 
Hakim, T. A., \& Bujang, I. (2012). The impact and consequences of tax revenues' components on economic indicators: Evidence from panel groups data. International Trade from Economic and Policy Perspective, 63, 82-95.

Harding, A., Söderbom, M., \& Teal, F. (2004). Survival and success among African manufacturing firms. Centre for the Study of African Economies, University of Oxford.

Harris, K. L. (1989). On requiring the correction of error under the federal tax law. The Tax Lawyer, 515-576.

Hart, P. E., \& Oulton, N. (1999). Gibrat, Galton and job generation. International Journal of the Economics of Business, 6(2), 149-164.

Hayes, A. F. (2013). Methodology in the social sciences: Introduction to mediation, moderation, and conditional process analysis: A regression-based approach. New York, US: The Guilford Press.

Hendricks, K., Amit, R., \& Whistler, D. (1997). Business taxation of small and medium-sized enterprises in Canada. The Committee.

Holban, O. I. (2007). The taxation of small and medium-sized enterprises-a hindering factor influencing the European economic growth. (Unpublished doctoral thesis), Alexandru Ioan Cuza University of Iasi and Academy of Economies Studies, Bucharest, Romania.

Huston, J. P. (2016). Pauper's parity: Taking away the fine print of your contribution is tax deductible. Geo. J. on Poverty L. \& Pol'y, 25, 115.

Inasius, F. (2015). Tax compliance of small medium enterprises in Indonesia: A case of retailer. IJMMR, 87.

Income Tax Act, 2015 Act 896.

Internal Revenue Service Act, 2000 Act 592.

James, S., dan Alley, C. (2002). Tax compliance, self-assessment and tax administration. Journal in Finance and Management in Public Services, 2(2), 27-42

Jackson, B. R., \& Milliron, V. C. (1986). Tax compliance research: Findings, problems, and prospects. Journal of Accounting Literature, 5(1), 125-165.

Jousten, A. (2007). SMEs and the tax system: What is so different about them? In CESifo Forum (Vol. 8, No. 2, pp. 14-20). München: ifo Institut für Wirtschaftsforschung an der Universität München.

Kannadhasan, M. (2009). Firm size as a moderator of the relationship between business strategy and performance in Indian automotive industry. Srusti Management Review, 2(2), 4-15.

Kasipillai, J., \& Abdul-Jabbar, H. (2006). Gender and ethnicity differences in tax compliance. Asian Academy of Management Journal, 11(2), 73-88.

Kendrick, M. S. (1939). The ability-to-pay theory of taxation. The American Economic Review, 92-101.

Kenyon, T., \& Kapaz, E. (2005). The informality trap. Public policy for the private sector (No. 301). Viewpoint Series Note

Kesselman, J. R. (1994). Canadian provincial payroll taxation: A structural and policy analysis. Department of Economics, University of British Columbia.

Kijkasiwat, P., \& Phuensane, P. (2020). Innovation and firm performance: The moderating and mediating roles of firm size and small and medium enterprise finance. Journal of Risk and Financial Management, $13(5), 97$.

Kinyua, A. N. (2014). Factors affecting the performance of small and medium enterprises in the Jua kali sector in Nakuru Town, Kenya. Journal of Business and Management, 6(1), 5-10.

Kirchler, E. (2007). The economic psychology of tax behaviour. Cambridge University Press.

Kiser, E., \& Karceski, S. M. (2017). Political economy of taxation. Annual Review of Political Science, 20, 75-92.

Koranteng, E. O., Osei-Bonsu, E., Ameyaw, F., Ameyaw, B., Agyeman, J. K., \& Dankwa, R. A. (2017). The effects of compliance and growth opinions on SMEs compliance decisions: An empirical evidence from Ghana. Open Journal of Business and Management, 5(02), 230.

Kraus, J. (2002). Capital, power and business associations in the African political economy: A tale of two countries, Ghana and Nigeria. The Journal of Modern African Studies, 40(3), 395-436.

Kumasi Business Advisory Center-Kumasi Metropolitan Assembly, 2017.

Kumasi Metropolitan Assembly Composite Budget Report, 2014.

Kuug, S. N. (2016). Factors influencing tax compliance of small and medium enterprises in Ghana. (Master's thesis). University of Ghana, Accra, Ghana

Kusi, L. Y., Domfeh, H. A., \& Kim, P. (2018). Impact of celebrity advertising on purchase intention of university students: The moderating role of celebrity advertising risk. WSEAS Transactions on Business and Economics, 15, 128-142.

Leedy, P. D., \& Ormrod, J. E. (2010). Practical research: Planning and design. (9 ${ }^{\text {th }}$ ed.). Pearson.

Lewis, V. L., \& Churchill, N. C. (1983). The five stages of small business growth. Harvard Business Review, 61(3), 30-50. 
Liakhovets, O. (2014). Tax Incentives Effectiveness for the innovation activity of industrial enterprises in Ukraine. Economics \& Sociology, 7(1), 72-84.

Lim, D. S., Morse, E. A., \& Yu, N. (2020). The impact of the global crisis on the growth of SMEs: A resource system perspective. International Small Business Journal, 38(6), 492-503.

Lokhande, M. N. G. (2020). The impressive changes digital businesses and technology are making on accounting. Studies in Indian Place Names, 40(61), 192-195.

Loo, E. C. (2006). Tax knowledge, tax structure and compliance: A report on a quasi-experiment. New Zealand Journal of Taxation Law and Policy, 12(2), 117-140.

Louis, D., \& Macamo, P. (2011). Barriers to business growth: A study on small enterprises in Maputo.

Markman, G. D., \& Gartner, W. B. (2002). The effects of hyper growth on firm profitability. The Journal of Private Equity, 58-65.

Marullo, C., Piccaluga, A., \& Cesaroni, F. (2020). How to invest in R \& D during a crisis? Exploring the differences between fast-growing and slow-growing Smes. Piccola Impresa/Small Business, (1).

Masanja, N. M. (2019). Major taxation challenges facing small and medium scale business enterprises in Tanzania.

Masato, A. (2009). Globalization of production and the competitiveness of small and medium-sized enterprises in Asia and the Pacific: Trends and prospects. Publication of United Nations Economic and Social Commission for Asia and the Pacific (ESCAP), Studies in Trade and Investment Series Chapter 1, 1-31.

Mayende, S. (2013). The effects of tax incentives on firm performance: Evidence from Uganda. J. Pol. \& L., 6, 95.

Mbizi, R., Hove, L., Thondhlana, A., \& Kakava, N. (2013). Innovation in SMEs: A review of its role to organisational performance and SMEs operations sustainability. Interdisciplinary Journal of Contemporary Research in Business, 4(11), 370-389.

Megersa, K. (2019). Review of tax incentives and their impacts in Asia.

Mohani, A. (2001). Personal income tax non-compliance in Malaysia. Melbourne: Victoria University.

Mukhlis, I., \& Simanjuntak, T. H. (2016). Tax compliance for businessmen of micro, small and medium enterprises sector in the regional economy. International Journal of Economics, Commerce and Management, 4(9), 116-126.

Mungaya, M., Mbwambo, A. H., \& Tripathi, S. K. (2012). Study of tax system impact on the growth of small and medium enterprises (SMEs): With reference to Shinyanga Municipality, Tanzania. International Journal of Management \& Business Studies, 2(3), 99-105.

Musamali, M. M., \& Tarus, D. K. (2013). Does firm profile influence financial access among small and medium enterprises in Kenya? Asian Economic and Financial Review, 3(6), 714.

Mwangi, P. C. N. (2014). Factors influencing tax compliance among small and medium enterprises in Nairobi's industrial area, Kenya. (Unpublished MA Project), University of Nairobi, Kenya.

Nastasiea, M., \& Mironeasa, C. (2019). Key performance indicators in small and medium sized enterprises. Total Quality Management, 1(2).

Neill, J. R. (2000). The benefit and sacrifice principles of taxation: A synthesis. Social Choice and Welfare, 17(1), 117-124.

Nguyen, T.D.K. \& Ramachandran, N. (2006). Capital structure in small and medium-sized enterprises: The case of Vietnam, ASEAN Economic Bulletin, 23 (2), 192-211.

Nkwe, N. (2012). Tax payers' attitude and compliance behavior among small medium enterprises (SMEs) in Botswana. Business and Management Horizons, 1(1), 113.

Nyarku, K. M., \& Oduro, S. (2017). Examining the Effect of Corruption and Bureaucracy on SMEs Growth in the Kumasi Metropolis of Ghana.

Ocheni, S. I., \& Gemade, T. I. (2015). Effects of multiple taxation on the performance of small and medium scale business enterprises in Benue State. International Journal of Academic Research in Business and Social Sciences, 5(3), 345.

Ohene, F. K. (2011). An assessment of tax compliance by the self-employed in the New Juaben Municipality. (Unpublished doctoral thesis), Kwame Nkrumah University of Science and Technology, Kumasi, Ghana.

Ojeka, S. (2011). Tax policy and the growth of SMEs: Implications for the Nigerian economy. Research Journal of Finance and Accounting, 2(2).

Ojo, A. T. (2003). Partnership and strategic alliance effective SME development. Small and medium enterprises development and SMIEIS: Effective implementation strategies. Lagos: CIBN Press Ltd.

Okpeyo, E. T., Musah, A., \& Gakpetor, E. D. (2019). Determinants of tax compliance in Ghana. Journal of Applied Accounting and Taxation, 4(1), 1-14.

Olawale, F., \& Garwe, D. (2010). Obstacles to the growth of new SMEs in South Africa: A principal component analysis approach. African Journal of Business Management, 4(5), 729-738.

Olorunshola, J. A. (2003, October). Problems and prospects of small and medium scale industries in Nigeria. In $C B N$ Seminar on SMIEIS (pp. 19-28). 
Osei, R. D., \& Quartey, P. (2005). Tax reforms in Ghana (No. 2005/66). WIDER Research Paper.

Pallant, J. (2005). SPSS survival manual: A step guide to data analysis using SPSS for Windows version 12.

Peci, F., Kutllovci, E., Tmava, Q., \& Shala, V. (2012). Small and medium enterprises facing institutional barriers in Kosovo. International Journal of Marketing Studies, 4(1), 95.

Pfister, M. (2009, November). Taxation for investment and development: An overview of policy challenges in Africa. In A Background paper to the Ministerial Meeting and Expert Roundtable of NEPAD-OECD Africa Investment Initiative (pp. 11-12).

Plehn, C. C. (1924). The concept of income, as recurrent, consumable receipts. The American Economic Review, 14(1), 1-12.

Prasad, E., Rogoff, K., Wei, S. J., \& Kose, M. A. (2005). Effects of financial globalization on developing countries: some empirical evidence. In India's and China's recent experience with reform and growth (pp. 201-228). Palgrave Macmillan, London.

PwC Ghana Report, 2014.

PwC Ghana, Ghana Tax Facts and Figures Report, 2019

Samuels, J. M. (1965). Size and the growth of firms. The Review of Economic Studies, 32(2), 105-112.

Scherf, R., \& Weinzierl, M. (2020). Understanding different approaches to benefit-based taxation. Fiscal Studies, 41(2), 385-410.

Singh, A., \& Whittington, G. (1975). The size and growth of firms. The Review of Economic Studies, 42(1), 15-26.

Singh, V. (2003). Malaysian tax administration.

Singh, V., \& Bhupalan, R. (2001). The Malaysian self-assessment system of taxation: Issues and challenges. Tax Nasional, 3, 12-17.

Siyanbola, T. T., Adedeji, S. B., Adegbie, F. F., \& Rahman, M. M. (2017). Tax incentives and industrial/economic growth of sub-Saharan African States. Journal of Advanced Research in Business and Management Studies, 7(2), 78-90.

Stella, B., Aggrey, N., \& Eseza, K. (2014). Firm size and rate of growth of Ugandan manufacturing firms. Journal of Applied Economics \& Business Research, 4(3).

Stewart, M. (2015). The tax state, benefit and legitimacy.

Stoilova, D. (2017). Tax structure and economic growth: Evidence from the European Union. Contaduria $y$ Administración, 62(3), 1041-1057.

Zee, H. H., Stotsky, J. G., \& Ley, E. (2002). Tax incentives for business investment: a primer for policy makers in developing countries. World development, 30(9), 1497-1516.

Stuebs Jr, M. T., \& Whiteaker-Poe, H. (2018). Making tax havens work: The necessity of tax professionalism. Accounting and the Public Interest, 18(1), 53-80.

Swistak, A. (2016). Tax penalties in SME tax compliance. Financial Theory and Practice, 40(1), 129-147.

Tee, E., Boadi, L., \& Opoku, R. (2016). The effect of tax payment on the performance of SMEs: The case of selected SMEs in Ga West municipal assembly. European Journal of Business and Management, 8(20).

Tehseen, S., Ramayah, T., \& Sajilan, S. (2017). Testing and controlling for common method variance: A review of available methods. Journal of Management Sciences, 4(2), 142-168.

Twesige, D., \& Gasheja, F. (2019). Effect of tax incentives on the growth of small and medium-sized enterprises (SMEs) in Rwanda: A case study of SMEs in Nyarugenge district. Journal of Accounting and Taxation, 11(5), 89-98.

Udechukwu, F. N. (2003). Survey of small and medium scale industries and their potentials in Nigeria. In SMIEIS seminar by the $C B N$.

Ugwu, J. I. (2018). Tax incentives and foreign direct investment (FDI): Implication for export promotion in Nigeria, Ghana and South Africa, Post IFRS Adoption. International Journal in Management \& Social Science, 6(9), 31-52.

Van Parys, S., \& James, S. (2010). The effectiveness of tax incentives in attracting FDI: Evidence from the tourism sector in the Caribbean. Gent, Universiteit Gent.

Wang, J., Zhang, Y., \& Goh, M. (2018). Moderating the role of firm size in sustainable performance improvement through sustainable supply chain management. Sustainability, 10(5), 1654.

Whittington, G. (1975). The size and growth of firms. Review of Economic Studies, 42(1), 15-26.

Wiklund, J., Patzelt, H., \& Shepherd, D. A. (2009). Building an integrative model of small business growth. Small Business Economics, 32(4), 351-374.

Williamson, O.E. (1998). Transaction cost economics: How it works; Where it is headed. De Economist 146, $23-58$. The World Bank Annual Report 2013.

Xu, B., Li, L., Liang, Y., \& Rahman, M. U. (2019). Measuring risk allocation of tax burden for small and micro enterprises. Sustainability, 11(3), 741. 
Yusof, N. A. M., Ling, L. M., \& Wah, Y. B. (2014). Tax non-compliance among SMCs in Malaysia: Tax audit evidence. Journal of Applied Accounting Research.

Zee, H. H., Stotsky, J. G., \& Ley, E. (2002). Tax incentives for business investment: a primer for policy makers in developing countries. World Development, 30(9), 1497-1516. 